\title{
Pengaruh Tata Bangunan dan Jalan terhadap Aliran Udara pada Kawasan Perkotaan
}

\author{
Effect of Buildings and Streets Configuration on Urban Area Airflow
}

\author{
Lestari $^{1}$ and Syaiful Muazir
}

Diterima: 27 November 2019

Disetujui: 8 Juli 2020

\begin{abstract}
Abstrak: Mendesain tatanan bangunan dan jalan pada kawasan dengan memaksimalkan pergerakan udara merupakan pendekatan untuk menghasilkan suatu kota berkelanjutan. Tatanan bangunan dan jalan- jalan dari suatu kawasan perkotaan dapat mempengaruhi iklim mikro yang terbentuk termasuk aliran udara yang terjadi. Aliran tersebut dapat dimanfaatkan untuk membentuk lingkungan kota yang nyaman. Jalan Gajahmada merupakan salah satu kawasan stategis secara ekonomi di Kota Pontianak yang memerlukan suatu kondisi nyaman dalam menunjang aktivitas yang terjadi di kawasan jalan tersebut. Aliran udara yang terjadi di sepanjang kawasan jalan tersebut mempengaruhi kondisi yang terjadi saat ini. Tulisan ini bertujuan untuk memberikan gambaran mengenai kondisi aliran udara yang terjadi pada kawasan jalan Gajahmada. Metode penelitian yang dilakukan adalah melalui simulasi komputer menggunakan program simulasi Envi-Met. Data yang digunakan berupa data iklim setempat dan data lapangan berdasarkan survey yang dilakukan. Melalui analisis yang telah dilakukan dapat diketahui bahwa aliran udara sangat dipengaruhi oleh arah angin, bentuk permukaan massa bangunan dan rasio antara tinggi bangunan dengan lebar jalan yang terbentuk dari jarak antar massa bangunan (H/W).
\end{abstract}

\section{Kata kunci: jalan, bangunan, aliran udara, Pontianak}

\begin{abstract}
Designing configuration of buildings and streets in an urban area by maximizing air movement is an approach of the sustainable city. The existing buildings and streets of an urban area can affect the microclimate formed, including the airflow. The airflow can be used to create a comfortable city environment. Jalan Gajahmada is one of the economic strategic areas in Pontianak City which requires a comfortable condition to support activities there. The airflow that occurs in Gajahmada Street affects the conditions that occur now. This paper aims to provide an overview of airflow conditions on Gajahmada Street Area. The research method is through computer simulations using the Envi-Met simulation program. The data used local climate data and field data based on surveys. Through the analysis, it is known that the airflow is strongly influenced by the direction of the wind, the surface mass of the building and the ratio between the height of the building to the width of the streets that is formed from the distance between building masses $(\mathrm{H} / \mathrm{W})$.
\end{abstract}

Keywords: street, building, airflow, Pontianak

\section{PENDAHULUAN}

Kota Pontianak merupakan ibu kota Kalimantan Barat yang secara geografis terletak berada di $0^{\circ} 02 " 24 "$ Lintang Utara dan $0^{\circ} 05^{\prime \prime} 37 "$ Lintang Selatan sehingga dikenal sebagai

\footnotetext{
${ }^{1}$ Jurusan Arsitektur, Fakultas Teknik, Universitas Tanjungpura
} 
Kota Khatulistiwa (Pontianak, 2019). Posisi geografis kota tersebut menyebabkan kota Pontianak mengalami panas sepanjang tahun yang dapat dilihat dari potensi energi matahari yang diperoleh untuk Kota Pontianak dapat dijadikan pembangkit listrik rumahan (Anggreni et al., 2018). Kondisi panas yang dialami Kota Pontianak juga berdampak pada iklim setempat terutama temperatur dan kelembaban di kota tersebut. Di aspek lain, keberadaan Kota Pontianak sebagai ibukota provinsi menyebabkan kota tersebut berkembang dengan cepat. Beberapa bagian kota tumbuh menjadi pusat industri serta pusat perdagangan dan jasa. Salah satu bagian kota yang tumbuh menjadi pusat perdagangan dan jasa adalah kawasan sepanjang jalan Gajahmada. Sepanjang jalan tersebut, dibangun bangunan-bangunan dengan fungsi yang beragam sehingga menghasilkan karakter bangunan yang juga beragam seperti ketinggian dan massa bangunan. Jalan-jalan sekunder yang berujung pada jalan Gajahmada juga semakin dipadati dengan bangunan-bangunan fungsi perdagangan dan jasa.

Jalan Gajahmada merupakan salah satu kawasan perdagangan di Kota Pontianak. Berdasarkan peruntukan lahan dalam Rencana Tata Ruang Wilayah Kota Pontianak tahun 2013-2033 (Pontianak, 2013), Jalan Gajahmada ditetapkan sebagai Kawasan Pusat Perbelanjaan. Selain itu, Jalan Gajahmada merupakan salah satu kawasan stategis secara ekonomi di Kota Pontianak. Hal ini dapat di lihat dari jumlah pembangunan fisik pada jalan tersebut yang terus bertumbuh. Hingga tahun 2018, telah dibangun hotel, pasar tradisional dan sejumlah pertokoan yang mempengaruhi fisik kawasan tersebut.

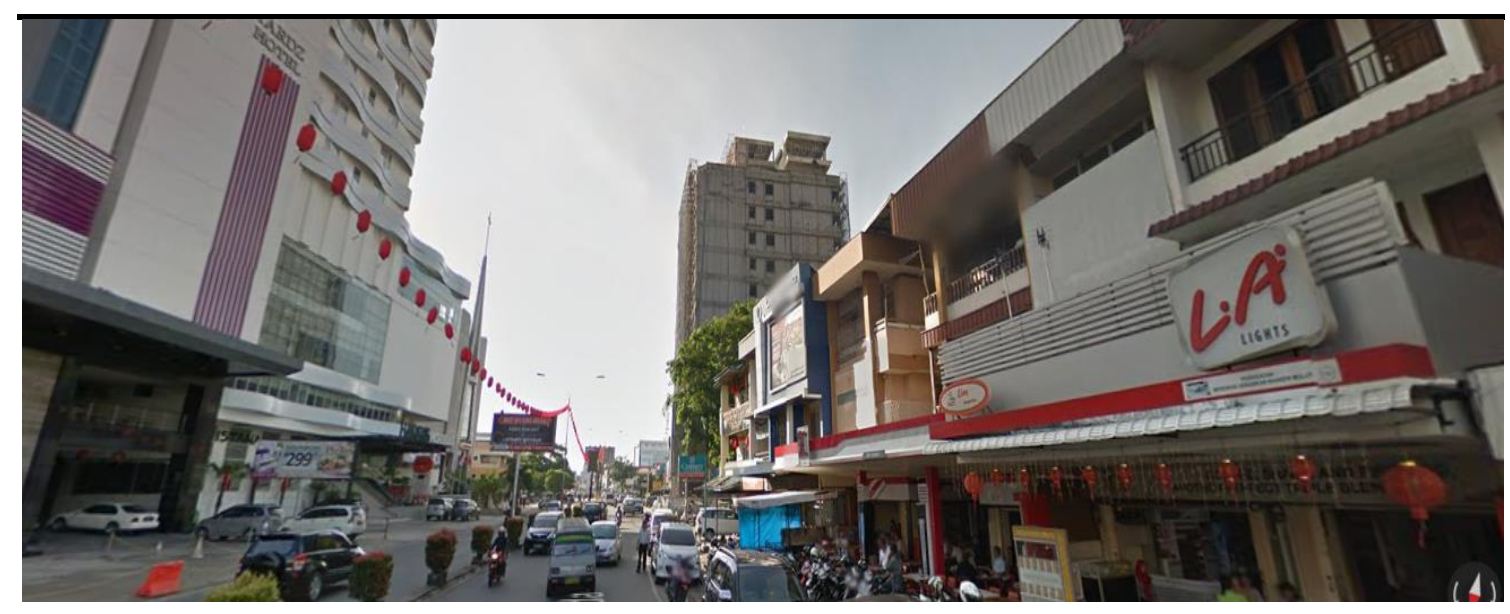

(Modifikasi dari google map, diakses Maret 2018)

\section{Gambar 1. Pembangunan di Jalan Gajah Mada Pontianak}

Konfigurasi massa bangunan dan jalan-jalan yang terbentuk dari suatu wilayah perkotaan mempengaruhi iklim mikro yang terbentuk. Elemen- elemen yang termasuk ke dalam iklim mikro diantaranya adalah aliran udara, radiasi matahari, panas, dan kelembaban (Erell et al., 2011). Kondisi bangunan dan konfigurasinya seperti dimensi dan jarak antar bangunan juga mempengaruhi iklim mikro yang terbentuk (Shashua-Bar et al., 2004). Geometri perkotaan juga mempengaruhi iklim mikro yang terbentuk, khususnya radiasi matahari yang diterima (Kakon \& Nobuo, 2009). Geometri urban canyon memiliki peran penting dalam membentuk panas di perkotaan (Bourbia \& Boucheriba, 2010).

Merancang suatu kawasan perkotaan melalui pengondisian iklim mikro yang terbentuk merupakan pendekatan untuk menghasilkan rancangan kota yang ramah lingkungan dan berkelanjutan. Aliran udara merupakan elemen iklim mikro yang dapat mempengaruhi kenyamanan suatu lokasi. Memanfaatkan sifat pergerakan udara dapat 
menjadi penyelesaian masalah kenyamanan di ruang kota. Seperti yang diungkapkan Erell et al. (2011) bahwa kunci penting untuk menyelesaikan masalah kenyamanan pejalan kaki serta ventilasi bangunan, kualitas udara, dan penggunaan energi adalah dengan memanfaatkan sifat gerakan udara (angin) di ruang kota. Shafaghat et al. (2016) juga mengungkapkan mengenai pentingnya pengaruh faktor bentuk dan susunan jalan terhadap pembentukan iklim mikro di kawasan, khususnya di iklim pantai tropis. Variabel desain jalan meliputi geometri jalan (rasio $\mathrm{H} / \mathrm{W}$ dan L / W), dimana W merupakan lebar jalan yang berbentuk antar massa bangunan, $\mathrm{H}$ merupakan tinggi bangunan dan L merupakan panjang bangunan sejajar jalan. Variabel tersebut mempengaruhi aliran udara yang terjadi pada kawasan perkotaan. Selain itu, orientasi jalan termasuk furnitur jalan juga mempengaruhi aliran udara dan akses matahari. Semuanya mempengaruhi kenyamanan termal pada jalur pejalan kaki. Aliran udara yang lebih baik tersedia pada urban canyon karena adanya pencampuran udara dari jalan yang lebar, di samping ventilasi yang terjadi di jalan dengan berbagai ketinggian bangunan (Shishegar, 2013). Orientasi jalan juga mempengaruhi kondisi nyaman yang terbentuk (Chatzidimitriou \& Axarli, 2017; AchourYounsi \& Kharrat, 2016). Urban canyon yang berorientasi utara selatan dengan rasio aspek sedang atau tinggi menghasilkan kondisi paling nyaman, sementara urban canyon berorientasi barat timur membutuhkan perlakuan tambahan untuk mendapatkan kondisi nyaman. Rasio H / W juga merupakan kunci dari desain yang dapat menghadirkan kondisi nyaman yang dapat diterima (Achour-Younsi \& Kharrat, 2016), di samping mempengaruhi jumlah energi matahari yang diperoleh oleh permukaan jalan (Shishegar, 2013). Sementara furnitur jalan seperti penutup kanopi pohon menurunkan kecepatan angin meskipun memberikan manfaat iklim mikro lainnya (Sanusi et al., 2016).

Aliran udara yang terjadi di daerah perkotaan juga mempengaruhi kualitas udara setempat. Pergerakan udara dari massa udara di street canyon memiliki efek signifikan terhadap dispersi polutan (Zhang et al., 2011). Peningkatan ketinggian bangunan di sekitar sumber polusi juga memberikan pengaruh terhadap kualitas udara (Aristodemou et al., 2018). Efek adanya peningkatan ketinggian bangunan (Aristodemou et al., 2018) menyebabkan peningkatan polusi dalam lokasi, dengan penyebaran polutan yang jauh lebih luas ke daerah yang sebelumnya bebas polusi, tetapi tingkat konsentrasi angin bawah umumnya berkurang.

Aliran udara di daerah perkotaan biasanya memiliki skala spasial dan temporal yang berbeda (Heidarinejad et al., 2017). Jalan Gadjah Mada sebagai daerah perdagangan memiliki karakteristik khusus dengan ketinggian bangunan yang beragam. Beberapa bangunan sangat berdekatan, tetapi beberapa bangunan terpisah terletak cukup jauh di sekitar jalan penghubung. Aktivitas yang terjadi di Jalan Gajahmada juga sangat padat, baik aktivitas kendaraan maupun pejalan kaki. Aktivitas kendaraan dan pejalan kaki terjadi siang dan malam. Area pinggir jalan secara spontan menjadi area pejalan kaki. Pejalan kaki memanfaatkan sisi di sepanjang jalan, tanpa kehadiran tempat teduh. Kenyamanan pengguna pejalan kaki, merupakan masalah penting mengingat kondisi geografis kota yang mengalami panas sepanjang tahun. Jalan Gajahmada memiliki pola aliran udara tertentu yang secara spasial mengambarkan pengaruh tatanan massa bangunan dan jalan yang telah terbentuk.

Kajian terhadap pergerakan udara yang terkait dengan tatanan massa bangunan dan jalan-jalan yang terbentuk pada kawasan menjadi informasi penting dan dapat dimanfaatkan sebagai potensi dalam pengembangan kawasan yang responsif terhadap iklim. Informasi terperinci tentang pola aliran udara sangat berguna bagi perancang sebagai dasar untuk mengembangkan daerah. Informasi ini digunakan untuk menyusun suatu kebijakan dalam penataan suatu kawasan sehingga pola aliran udara termasuk kecepatan pergerakan udara dapat dimanfaatkan untuk mendapatkan kondisi yang nyaman bagi pengguna. 


\section{METODE}

Penelitian ini mengambil lokasi di kawasan sekitar Jalan Gajahmada. Metodologi yang digunakan untuk mengevaluasi aliran udara yang terjadi adalah menggunakan teknik simulasi komputer. Program Envi-Met dipilih karena bisa memberikan informasi yang cukup detail mengenai pergerakan angin yang terjadi pada kawasan. Informasi yang detail mengenai kondisi iklim mikro khususnya pergerakan angin dalam kawasan secara umum dapat diperoleh melalui pengukuran langsung dan menggunakan modeling. Penelitianpenelitian iklim mikro perkotaan awalnya dilakukan melalui metode observasi seperti pengukuran di lapangan. Perkembangan dan kemajuan teknologi komputasi memunculkan pendekatan simulasi numerik yang menggunakan modeling. Pengukuran langsung dan modeling dapat digunakan dalam proses perencanaan kota dan bangunan yang responsif terhadap perubahan iklim (Elnabawi et al., 2013). Penggunaan wind-tunnel dan teknik CFD dapat menghasilkan gambaran hasil yang cukup akurat (Blocken et al., 2016). Namun, program simulasi computer seperti Envi-Met dapat memberikan gambaran perkiraan perubahan kondisi iklim di kota-kota berdasarkan hasil studi yang telah dilakukan (Langer et al., 2012). Hal ini di dukung oleh Elnabawi et al. (2013) yang menyebutkan bahwa simulasi kondisi iklim mikro dengan menggunakan Envi-Met, dapat menyajikan hasil perkiraan yang cukup baik.

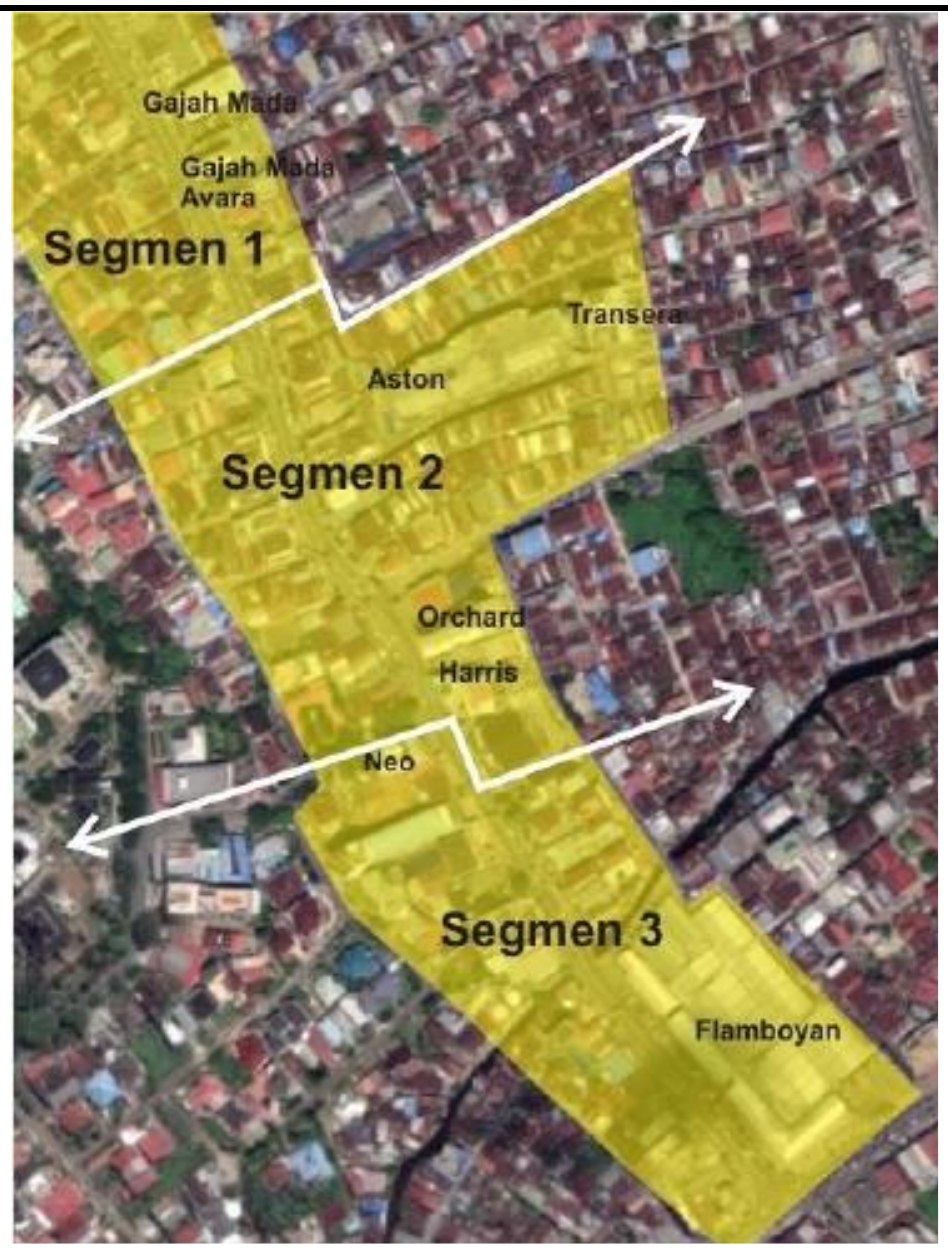

(Modifikasi dari google map, diakses Maret 2018)

Gambar 2. Pembagian Segmen Kawasan Penelitian 
Studi simulasi terhadap kondisi pergerakan udara pada jalan Gajahmada menggunakan beberapa waktu yang representatif. Seperti yang dipelajari oleh Heidarinejad et al. (2017), simulasi terhadap pergerakan udara dapat dibatasi pada beberapa sample waktu. Hal ini dilakukan karena adanya keterbatasan kapasitas penyimpanan komputer. Pada studi ini untuk mempermudah kinerja dalam simulasi, kawasan juga dibagi menjadi 3 segmen dengan pertimbangan kedetailan dari perangkat software yang digunakan, selain perbedaan tipikal fisik bangunan pada setiap segmen. Untuk kepentingan tersebut, kawasan ini dibagi menjadi 3 segmen seperti gambar berikut. Waktu simulasi dipilih pada 4 waktu yaitu 21 Maret, 21 Juni, 23 September, dan 21 Desember.

berikut:

Langkah-langkah yang dilakukan dalam penelitian ini secara umum adalah sebagai

1. Melakukan survey lapangan untuk mendapatkan data primer mengenai kondisi eksisting jalan Gajahmada dan mengumpulkan data sekunder cuaca dan iklim setempat.

2. Membuat model kawasan dan melakukan input data-data cuaca dan iklim makro pada program simulasi Envi-Met.

3. Melakukan simulasi kondisi aliran udara berdasarkan 4 waktu yang dipilih.

4. Melakukan evaluasi terhadap pola aliran udara dan kecepatan pergerakannya serta pengaruh kondisi jalan Gajahmada terhadap pergerakan udara tersebut.

\section{HASIL DAN PEMBAHASAN}

Hasil identifikasi awal terhadap beberapa karakteristik kawasan yang memiliki pengaruh terhadap pergerakan udara adalah jarak antar bangunan (ruang terbuka) dan ketinggian bangunan. Jarak antar bangunan terutama terbentuk karena jalur jalan yang ada. Sebagian besar bangunan saling bersinggungan sehingga tidak ada jarak antar bangunan. Terdapat beberapa ruang terbuka antar bangunan terutama di area yang cukup jauh dengan jalan utama. Kondisi jarak antar bangunan yang terdapat di jalan Gajahmada dapat terlihat seperti Tabel 1.

Tabel 1. Kondisi Jarak Antar Bangunan

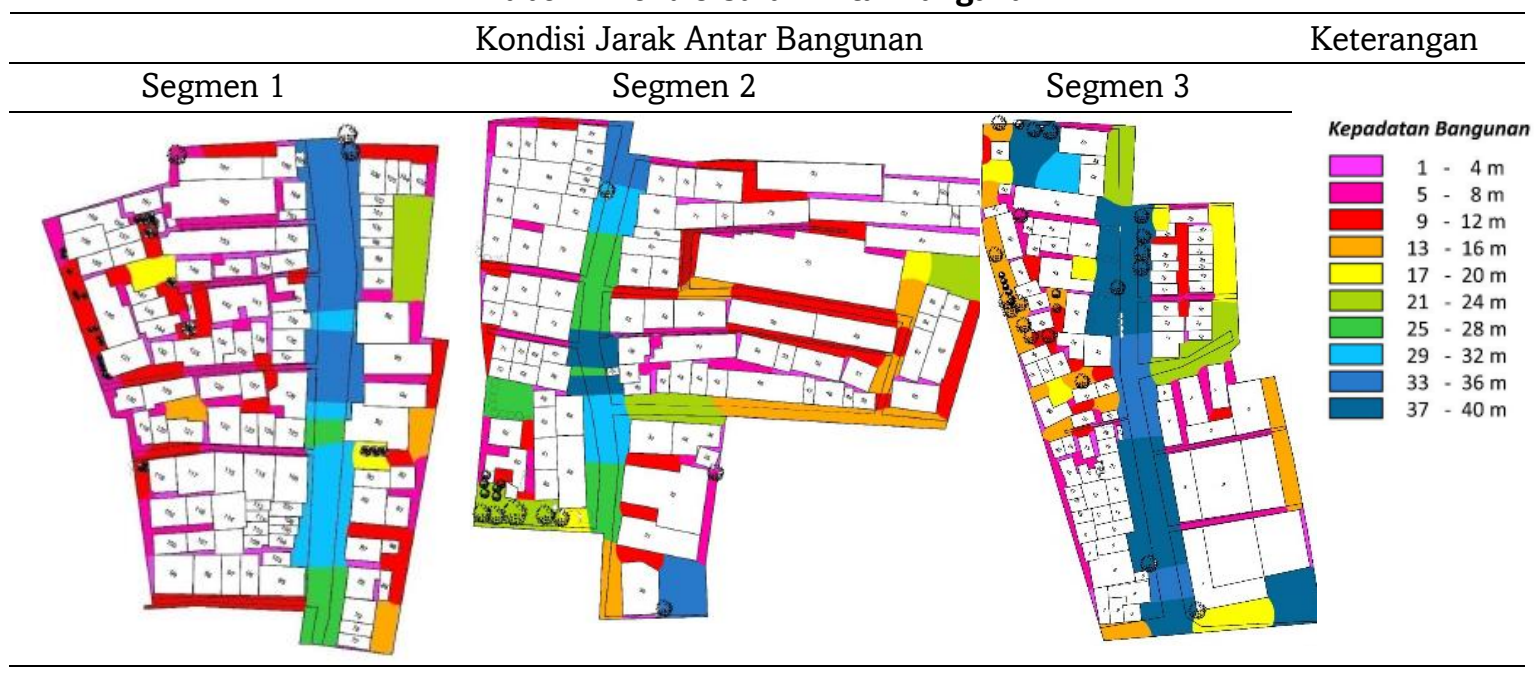

Sumber: Penulis, 2018

Ketinggian bangunan juga bervariasi mulai dari ketinggian sekitar 4 meter (1 lantai) sampai dengan ketinggian sekitar 40 meter. Bangunan yang berada di jalan utama Gadjahmada sebagian besar memiliki ketinggian sekitar 8-12 meter. Hanya terdapat beberapa bangunan yang ketinggiannya mencapai 40 meter. Kondisi ketinggian bangunan yang terdapat di jalan Gajahmada dapat terlihat seperti Tabel 2. 
Tabel 2. Kondisi Ketinggian Bangunan

\begin{tabular}{cccc}
\hline \multicolumn{1}{c}{ Kondisi Ketinggian Bangunan } & Keterangan \\
\hline Segmen 1 & Segmen 2 & Segmen 3 \\
\hline & & & \\
\hline
\end{tabular}

Sumber: Penulis, 2018

Hasil simulasi yang telah dilakukan pada ketiga segmen pada 4 waktu yang dipilih dapat terlihat dari grafik-grafik yang ditunjukkan oleh Gambar 3 - Gambar 5. Pada segmen pertama terjadi perubahan pergerakan aliran udara dan kecepatannya. Kecepatan pergerakan udara terjadi bervasiasi mulai dari dibawah $0,5 \mathrm{~m} / \mathrm{s}$ sampai dengan diatas 3 $\mathrm{m} / \mathrm{s}$. Kecepatan pergerakan udara yang nyaman bagi manusia adalah berkisar 0,5 s/d 1,5 $\mathrm{m} / \mathrm{s}$ (Szokolay, 2008) dan untuk iklim tropis yang panas dapat mencapai $2 \mathrm{~m} / \mathrm{s}$. Kondisi kecepatan aliran udara pada segmen 1 yang dievaluasi dari 4 waktu, sebagian besar menunjukkan nyaman dan berada pada rentang kecepatan yang dipersyaratkan seperti yang ditunjukkan pada Gambar 3. Kecepatan pergerakan udara rendah dibawah kondisi nyaman dapat terlihat terjadi pada jalan-jalan yang tertutup (buntu). Pada jalan-jalan yang terhubung (membentuk lorong) dengan rasio H/W antara 0,65 sampai dengan 1,6 justru memiliki kecepatan pergerakan udara lebih tinggi dibandingkan sekitarnya.

Pola pergerakan udara yang menerus, tanpa terhalang massa bangunan juga menghasilkan kecepatan pergerakan yang lebih cepat. Kecepatan pergerakan udara pada daerah dekat permukaan bangunan cenderung lebih lambat dibandingkan yang berada jauh dari permukaan bangunan. Hal ini akibat adanya tumbukan udara dengan massa bangunan tersebut. Padahal, letak-letak pedestrian umumnya berada disisi-sisi bangunan. Perubahan dimensi ruang bebas antar bangunan (W) menghasilkan perubahan pola pergerakan dan kecepatan udara. Perbandingan panjang massa bangunan (L) dengan jarak antar bangunan (W), L/W, yang lebih rendah cenderung menghasilkan perubahan arah pergerakan udara.

Pada Segmen 2 kondisi pergerakan aliran udara dan kecepatannya juga menunjukkan fenomena yang mirip dengan Segmen 1. Pola pergerakan aliran udara dan kecepatannya pada Segmen ke 2 dapat dilihat pada Gambar 4. Sebagian besar kecepatan aliran udara yang terjadi pada Segmen 2 juga berada pada kondisi nyaman. Pada beberapa kondisi seperti posisi jalan yang tegak lurus terhadap arah datang angin, menghasilkan kecepatan yang cukup rendah sepanjang jalan tersebut. Hal ini akibat terhalangnya pergerakan angin yang dapat terlihat dari pola pergerakan angin yang terbentuk. Bentuk permukaan bangunan yang tidak menerus (masa bangunan maju-mundur) juga menghambat pergerakan udara sehingga kecepatan yang dihasilkan lebih rendah. Dengan demikian perbandingan L/W juga mempengaruhi pergerakan aliran udara dan kecepatan yang terjadi.

Seperti halnya pada segmen 1, kecepatan aliran udara yang berada di dekat permukaan bangunan cenderung lebih rendah dibandingkan yang lebih jauh dari 
permukaan bangunan, akibat adanya tumbukan angin dengan massa bangunan. Pada kondisi jalan-jalan buntu, kecepatan aliran udara yang dihasilkan juga cukup rendah. Jalanjalan yang berbentuk lorong panjang cenderung menghasilkan kecepatan aliran udara yang cukup baik dan pola pergerakan yang lebih stabil. Pada segmen ini kondisi nyaman bagi pengguna ditemui terjadi pada rasio H/W sekitar 0,5.

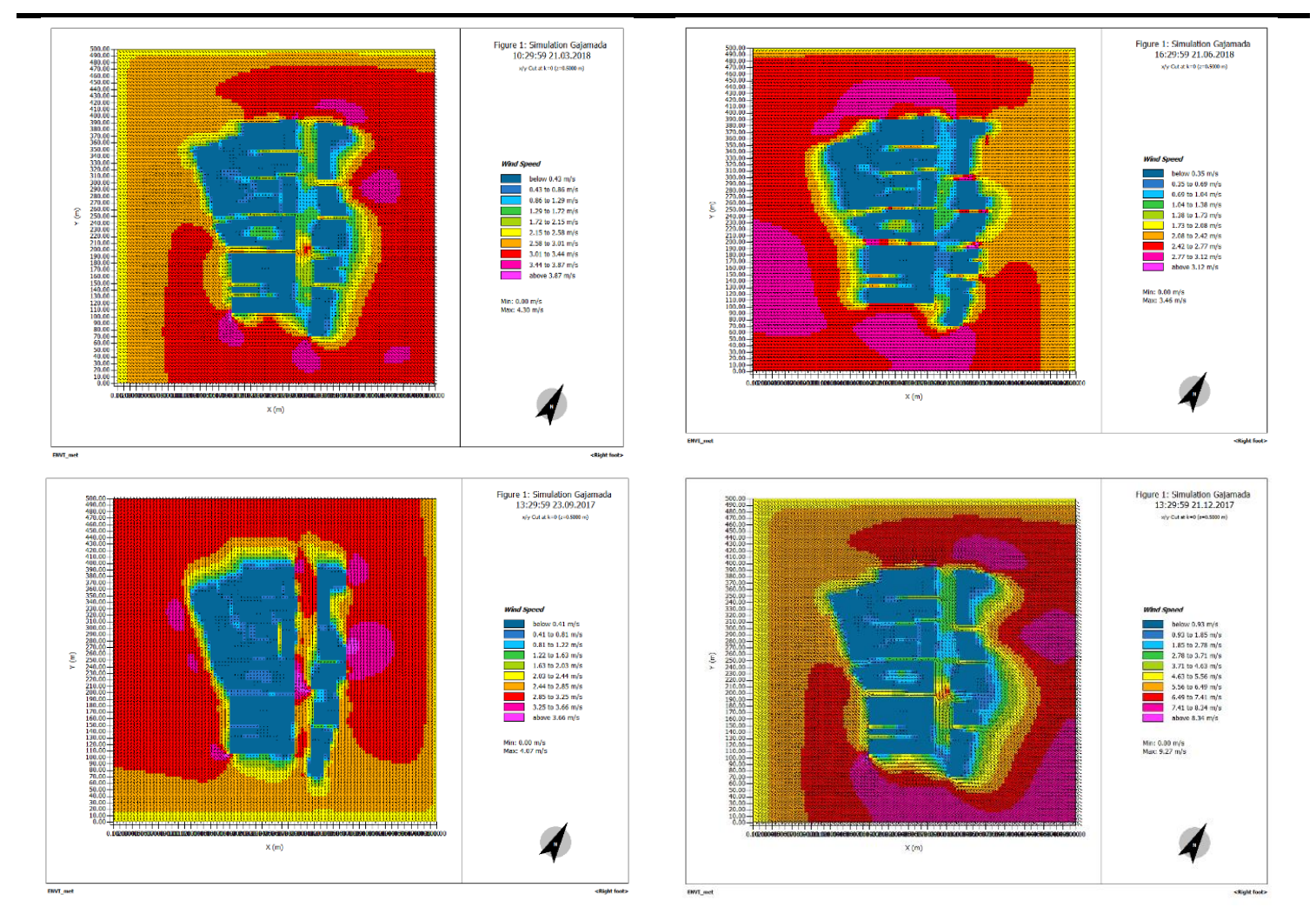

Sumber: Penulis, 2019

\section{Gambar 3. Hasil Simulasi Pola Pergerakan dan Kecepatan Udara di Segmen 1 pada 4 Waktu ( Kiri-Kanan : Maret, Juni, September dan Desember)}

Pola pergerakan dan kecepatan angin pada Segmen 3 dapat dilihat pada Gambar 5. Karakteristik jalan di Segmen 3 memiliki perbedaan dibandingkan 2 segmen sebelumnya. Selain tersedianya area terbuka di beberapa titik terutama di belakang massa bangunan, juga adanya massa bangunan yang besar memanjang dengan rasio $\mathrm{H} / \mathrm{W}$ dan $\mathrm{L} / \mathrm{W}$ yang hamper sama. Area tersebut cukup mendominasi dengan rasio H/W sekitar 0,3. Dengan karakteristik tersebut, dapat terlihat bahwa pada segmen ini, area dengan rasio 0,3 memiliki potensi kecepatan aliran udara yang baik saat arah datang angin sejajar dengan orientasi jalan. Namun, ketika arah datang angin berlawanan dengan orientasinya, maka kecepatan aliran udara yang dihasilkan juga semakin menurun. Jalan-jalan yang berbentuk lorong panjang terdapat di antara masa-masa bangunan yang besar dengan rasio H/W yang cukup besar yaitu sekitar 2,4. Pola pergerakan aliran udara yang terlihat pada loronglorong panjang tersebut menghasilkan pola pergerakan yang lebih stabil, namun menghasilkan kecepatan angin yang rendah.

Ruang terbuka antar bangunan yang cukup luas terlihat memberikan ruang pergerakan udara di daerah tersebut. Pada ruang terbuka tersebut, terjadi pola pergerakan aliran udara yang cenderung menyebar di bagian terluar dan memusat di bagian 
tengahnya. Kecenderungan kecepatan udara yang melambat di daerah yang berdekatan permukaan bangunan juga dapat diamati terjadi pada segmen ini. Semakin besar jarak antar bangunan (W besar), area yang mendapatkan udara dengan kecepatan lambat semakin lebih luas, dibandingkan jika jarak antar bangunan lebih sempit (W kecil).
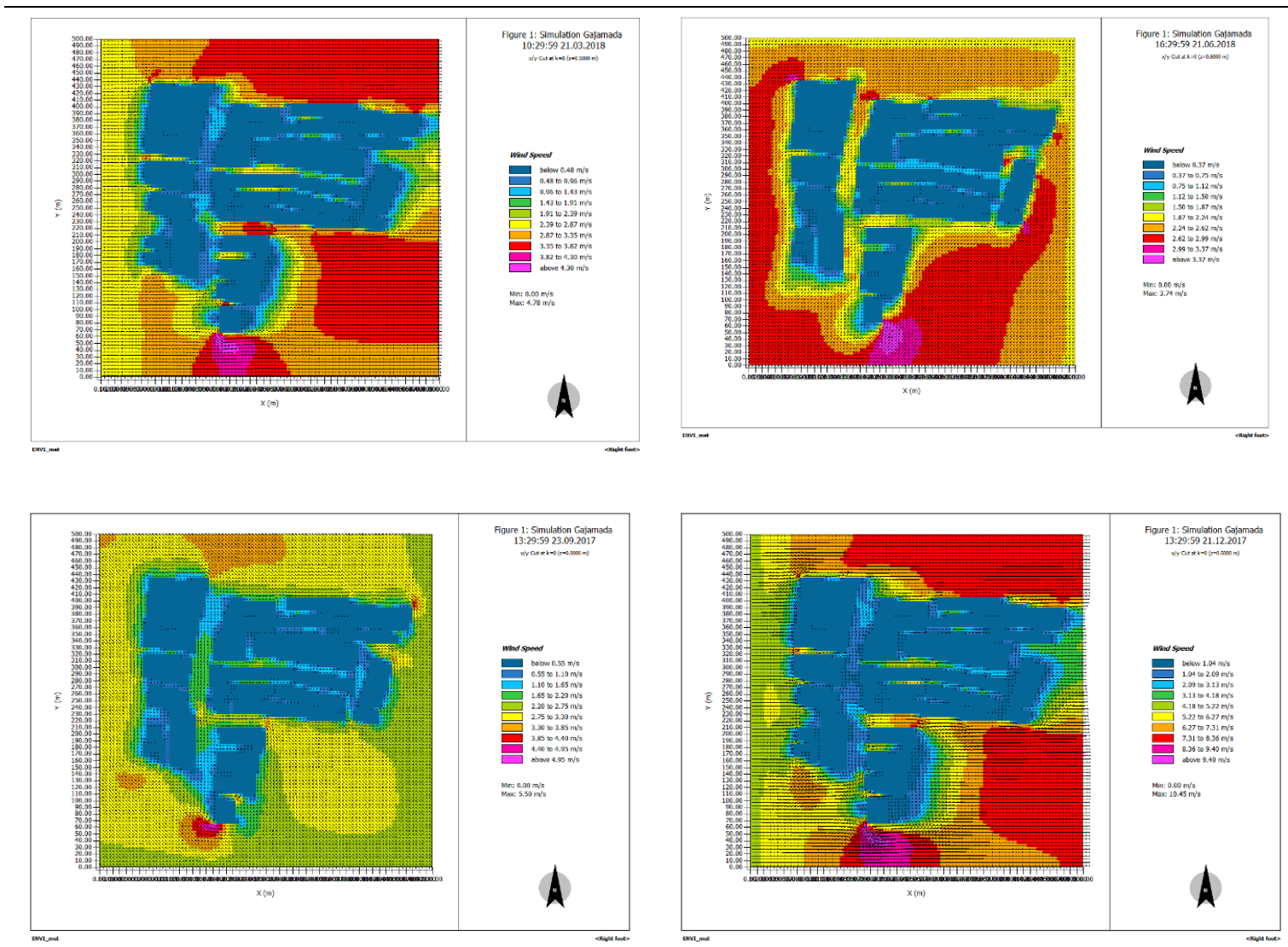

Sumber: Penulis, 2019

\section{Gambar 4. Hasil Simulasi Pola Pergerakan dan Kecepatan Udara di Segmen 2 pada 4 Waktu ( Kiri-Kanan : Maret, Juni, September dan Desember)}

Hasil analisis ini memberikan gambaran bahwa kondisi fisik yang terbentuk pada kawasan Jalan Gadjahmada Pontianak, seperti tatanan massa bangunan dan jalan-jalan yang terbentuk mempengaruhi iklim mikro yang terbentuk. Hal ini sejalan dengan penelitian-penelitian yang telah dilakukan sebelumnya (Shafaghat et al., 2016; Shishegar, 2013; Erell, Pearlmutter, and Williamson, 2011; Shashua-Bar, Tzamir, and Hoffman, 2004). Hasil penelitian ini memperkuat argumentasi terhadap hasil penelitian sebelumnya bahwa hal ini juga berlaku di kawasan Jalan Gadjahmada Pontianak yang memiliki iklim tropis lembab. Namun, penelitian yang dilakukan ini, dapat menyajikan informasi secara detail dan dalam bentuk visual mengenai hubungan interaksi antara tatanan bangunan dengan perubahan pergerakan udara, khususnya di Jalan Gadjahmada Pontianak, yang belum diperoleh dari penelitian-penelitian yang telah dikaji sebelumnya. Perbandingan pergerakan udara yang terjadi juga dapat secara detail ditunjukkan dari waktu-waktu simulasi sehingga kesimpulan dapat mewakili fenomena dari berbagai waktu dan kondisi. 

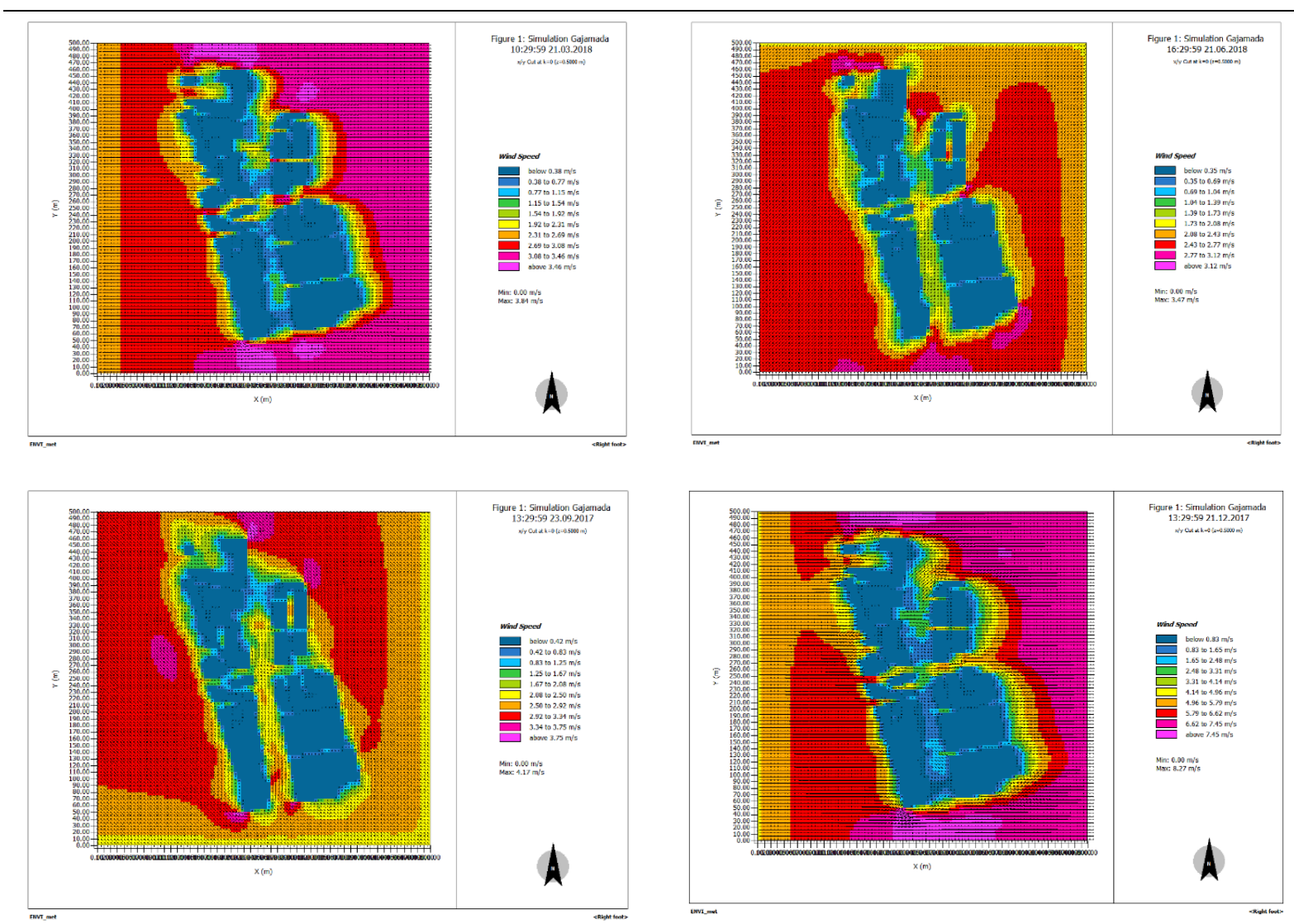

Sumber: Penulis, 2019

\section{Gambar 5. Hasil Simulasi Pola Pergerakan dan Kecepatan Udara di Segmen 3 pada 4 Waktu ( Kiri-Kanan : Maret, Juni, September dan Desember)}

\section{KESIMPULAN}

Pola pergerakan aliran udara dan kecepatannya yang dievaluasi dari simulasi pada ketiga segmen kawasan memberikan gambaran bahwa pergerakan udara dan kecepatannya dipengaruhi oleh arah datang angin pada daerah tersebut. Aliran udara memiliki pergerakan yang menerus lurus pada jalan-jalan yang terbentuk dengan orientasi searah dengan arah datang angin. Sebaliknya orientasi jalan yang tegak lurus dengan arah datang angin cenderung memiliki pergerakan yang lebih lambat.

Selain arah datangnya angin pada kawasan, bentuk permukaan massa bangunan juga mempengaruhi pergerakan udara yang terjadi. Massa-massa bangunan yang memiliki permukaan maju mundur cenderung mengubah arah gerak aliran udara dan memperlambat pergerakannya. Hal ini juga dapat disimpulkan bahwa perbandingan $\mathrm{L}$ terhadap W sangat mempengaruhi pergerakan udara yang terjadi. Susunan massa bangunan yang membentuk lorong membantu udara bergerak lurus dan tidak terhambat pergerakannya. Aliran udara di sekitar permukaan bangunan cenderung mengalami tumbukan dengan permukaan bangunan tersebut sehingga menghasilkan pergerakan yang berbalik dan melambat kecepatannya. Kondisi kecepatan yang nyaman menurut Szokolay (2008) dapat dicapai di jalan ini pada H/W sekitar 0,5.

Informasi mengenai pergerakan udara pada kawasan penting bagi perancang perkotaan untuk mempertimbangkan kondisi tatanan massa bangunan dan jalan-jalan pada suatu daerah perencanaan sehingga dapat memaksimalkan pergerakan udara yang 
menguntungkan untuk kenyamanan. Penelitian dengan kasus spesifik kawasan Jalan Gadjahmada Pontianak seperti ini dapat pula dilakukan pada kasus-kasus lain sehingga dapat memberikan gambaran yang lebih kuat mengenai pergerakan udara pada kawasan. Penggunaan program simulasi yang lain juga bisa memperkuat hasil kesimpulan pada tulisan ini.

\section{DAFTAR PUSTAKA}

Achour-Younsi, S., \& Kharrat, F. (2016). Outdoor Thermal Comfort: Impact of the Geometry of an Urban Street Canyon in a Mediterranean Subtropical Climate - Case Study Tunis, Tunisia. Procedia - Social and Behavioral Sciences, 216(October 2015), 689-700. https://doi.org/10.1016/j.sbspro.2015.12.062

Anggreni, R., Muliadi, \& Adriat, R. (2018). Analisis Pengaruh Tutupan Awan Terhadap Radiasi Matahari di Kota Pontianak. Prisma Fisika, 6(3), 214-219.

Aristodemou, E., Boganegra, L. M., Mottet, L., Pavlidis, D., Constantinou, A., Pain, C., Robins, A., \& ApSimon, H. (2018). How Tall Buildings Affect Turbulent Air Flows and Dispersion of Pollution Within a Neighbourhood. Environmental Pollution, 233, 782-796. https://doi.org/10.1016/j.envpol.2017.10.041

Blocken, B., Stathopoulos, T., \& van Beeck, J. P. A. J. (2016). Pedestrian-Level Wind Conditions Around Buildings: Review of Wind-Tunnel and CFD Techniques and Their Accuracy for Wind Comfort Assessment. Building and Environment, 100, 50-81. https://doi.org/10.1016/j.buildenv.2016.02.004

Bourbia, F., \& Boucheriba, F. (2010). Impact of Street Design on Urban Microclimate for Semi Arid Climate (Constantine). Renewable Energy, 35(2), 343-347. https://doi.org/10.1016/j.renene.2009.07.017

Chatzidimitriou, A., \& Axarli, K. (2017). Street Canyon Geometry Effects on Microclimate and Comfort; A Case Study in Thessaloniki. Procedia Environmental Sciences, 38, 643-650. https://doi.org/10.1016/j.proenv.2017.03.144

Elnabawi, M., Hamza, N., \& Dudek, S. (2013). Use and Evaluation of the ENVI-MET Model for Two Different Urban Forms in Cairo, Egypt: Measurements and Model. 13th Conference of Internatioanl Building Performance Simulation Association, 2800-2806.

Erell, E., Pearlmutter, D., \& Williamson, T. (2011). Urban Microclimate Designing the Spaces Between Buildings. Taylor \& Francis.

Heidarinejad, M., Nikkho, S. K., Liu, J., Mattise, N., \& Srebric, J. (2017). Quantify Impacts of Local Urban Microclimate on Local Airflow Patterns. Procedia Engineering, 205, 1983-1989. https://doi.org/10.1016/j.proeng.2017.10.067

Kakon, A., \& Nobuo, M. (2009). The Sky View Factor Effect on the Microclimate of a City Environment: A Case Study of Dhaka City. 7th International Conference on Urban Climate, April 2008, 7-10. http://www.ide.titech.ac.jp/ icuc7/extended_abstracts/pdf/384760-1-090513144446-003.pdf

Langer, I., Sodoudi, S., \& Cubasch, U. (2012). Using the ENVI-MET Program to Simulate the Micro Climate in New Town HASHTGERD. The International Conference On Computing, Networking and Digital Technologies, 61-64. https://doi.org/10.13140/2.1.1739.2005

Pontianak, P. K. (2013). Peraturan Daerah Kota Pontianak No 2 Tahun 2013 Tentang Rencana Tata Ruang Wilayah Kota Pontianak Tahun 2013-2033 (pp. 37-39). Sekretaris Daerah Pemerintah Kota Pontianak.

Pontianak, P. K. (2019). Kondisi Geografis Kota Pontianak. https://www.pontianakkota.go.id/tentang/geografis [Accessed 21 Mei 2019]

Sanusi, R., Johnstone, D., May, P., \& Livesley, S. J. (2016). Street Orientation and Side of the Street Greatly Influence the Microclimatic Benefits Street Trees Can Provide in Summer. Journal of Environmental Quality, 45(1), 167-174. https://doi.org/10.2134/jeq2015.01.0039

Shafaghat, A., Manteghi, G., Keyvanfar, A., Bin Lamit, H., Saito, K., \& Ossen, D. R. (2016). Street Geometry Factors Influence Urban Microclimate in Tropical Coastal Cities: A Review. Environmental and Climate Technologies, 17(1), 61-75. https://doi.org/10.1515/rtuect-2016-0006

Shashua-Bar, L., Tzamir, Y., \& Hoffman, M. E. (2004). Thermal Effects of Building Geometry and Spacing on the Urban Canopy Layer Microclimate in a Hot-Humid Climate in Summer. International Journal of Climatology, 24(13), 1729-1742. https://doi.org/10.1002/joc.1092

Shishegar, N. (2013). Street Design and Urban Microclimate: Analyzing the Effects of Street Geometry and Orientation on Airflowand Solar Access in Urban Canyons. Journal of Clean Energy Technologies, 1(1), 52-56. https://doi.org/10.7763/jocet.2013.v1.13

Szokolay, S. V. (2008). Introduction to Architectural Science - The Basis of Sustainable Design. Architectural Press.

Zhang, Y. W., Gu, Z. L., Cheng, Y., \& Lee, S. C. (2011). Effect of Real-Time Boundary Wind Conditions on The Air Flow and Pollutant Dispersion in an Urban Street Canyon-Large Eddy Simulations. Atmospheric Environment, 45(20), 3352-3359. https://doi.org/10.1016/j.atmosenv.2011.03.055 